\begin{tabular}{|l|l|l|}
\hline \multicolumn{2}{|c|}{ PublisherInfo } \\
\hline \hline PublisherName & $:$ & BioMed Central \\
\hline \hline PublisherLocation & $:$ & London \\
\hline \hline PublisherImprintName & $:$ & BioMed Central \\
\hline \hline
\end{tabular}

\title{
Articles selected by Faculty of 1000: identifying pol III- dependent genes; entomopathogen genome; microbial genome dynamics; profiling ES cells; gene expression regulation by small RNAs
}

\begin{tabular}{||l|l|l||}
\hline \multicolumn{2}{|c||}{ ArticleInfo } \\
\hline \hline ArticleID & $:$ & 3475 \\
\hline \hline ArticleDOI & $:$ & $10.1186 /$ gb-2003-4-11-349 \\
\hline \hline ArticleCitationID & $:$ & 349 \\
\hline \hline ArticleSequenceNumber & $:$ & 19 \\
\hline \hline ArticleCategory & $:$ & Paper report \\
\hline \hline ArticleFirstPage & $:$ & 1 \\
\hline \hline ArticleLastPage & $:$ & 3 \\
\hline \hline & & RegistrationDate $:$ 2003-10-17 \\
ArticleHistory & $:$ & OnlineDate $\quad$ 2003-10-17 \\
\hline \hline
\end{tabular}




\begin{tabular}{|l|l|l||}
\hline ArticleCopyright & $:$ & BioMed Central Ltd2003 \\
\hline \hline ArticleGrants & $:$ & \\
\hline \hline ArticleContext & $:$ & 13059441111 \\
\hline
\end{tabular}

\section{Identifying pol III-dependent genes}

A selection of evaluations from Faculty of $\mathbf{1 0 0 0}$ covering the identification of pol III-dependent genes, the genome sequence of Photorhabdus luminescens, microbial genome dynamics, profiling ES cells and gene expression regulation by small RNAs.

Genome-wide location of yeast RNA polymerase III transcription machinery. Harismendy O, Gendrel CG, Soularue P, Gidrol X, Sentenac A, Werner M, Lefebvre O. EMBO J 2003, 22:4738-4747.

For the Faculty of 1000 evaluation of this article please see: http://genomebiology.com/reports/F1000/ gb-2003-4-11-349.asp\#Harismendy

\section{Entomopathogen genome}

The genome sequence of the entomopathogenic bacterium Photorhabdus luminescens . Duchaud E, Rusniok C, Frangeul L, Buchrieser C, Givaudan A, Taourit S, Bocs S, Boursaux-Eude C, Chandler M, Charles JF, et al. Nat Biotechnol 2003, Oct 5.

For the Faculty of 1000 evaluation of this article please see: http://genomebiology.com/reports/F1000/ gb-2003-4-11-349.asp\#Duchaud

\section{Microbial genome dynamics}

Horizontal gene transfer accelerates genome innovation and evolution. Jain R, Rivera MC, Moore JE, Lake JA. Mol Biol Evol 2003, 20:1598-1602.

For the Faculty of 1000 evaluation of this article please see: http://genomebiology.com/reports/F1000/ gb-2003-4-11-349.asp\#Jain 


\section{Profiling ES cells}

Molecular signature of human embryonic stem cells and its comparison with the mouse. Sato N, Sanjuan IM, Heke M, Uchida M, Naef F, Brivanlou AH. Dev Biol 2003, 260:404-413.

For the Faculty of 1000 evaluation of this article please see: http://genomebiology.com/reports/F1000/ gb-2003-4-11-349.asp\#Sato

\section{Gene expression regulation by small RNAs}

Coupled degradation of a small regulatory RNA and its mRNA targets in Escherichia coli . Masse E, Escorcia FE, Gottesman S. Genes Dev 2003, 17:2374-2383.

For the Faculty of 1000 evaluation of this article please see: http://genomebiology.com/reports/F1000/ gb-2003-4-11-349.asp\#Masse 